\title{
Pengaruh Kecerdasan Emosional dan Minat Belajar Terhadap Prestasi Belajar
}

\author{
Ajang Mulyadi \\ Shinta Wahyuni \\ Prodi Pendidikan Akuntansi FPEB UPI \\ ajangmulyadi@upi.edu
}

\begin{abstract}
Abstrak
Penelitian ini bertujuan untuk mengetahui pengaruh kecerdasan emosional dan minat belajar terhadap prestasi belajar mahasiswa Pendidikan Akuntansi UPI Bandung. Penelitian ini menggunakan metode survey dengan desain penelitian korelasional. Pengumpulan data dilakukan dengan menggunakan angket yang telah diuji validitas dan reliabilitasnya. Data diolah dengan menggunakan statistik parametrik dengan teknik analisis regresi multiple. Penarikan kesimpulan hasil penelitian menggunakan tingkat kepercayaan $95 \%$. Hasil penelitian menunjukkan bahwa kecerdasan emosional dan minat belajar memiliki pengaruh positif terhadap prestasi belajar mahasiswa. Implikasi dari hasil penelitian yang disarankan peneliti adalah bahwa para mahasiswa harus dapat lebih mengendalikan emosinya dan lebih mandiri dalam belajar untuk memperoleh prestasi belajar yang lebih baik.
\end{abstract}

Kata Kunci : Kecerdasan Emosional, Minat Belajar, Prestasi Belajar, Indeks Prestasi Kumulatif (IPK)

\section{Pendahuluan}

Pendidikan bagi kehidupan
manusia merupakan kebutuhan mutlak yang harus dipenuhi sepanjang hayat. Pendidikan berlangsung melalui tahap-tahap berkesinambungan (prosedural) dan sistematik karena berlangsung dalam semua situasi kondisi, pada semua lingkungan yang saling mengisi (lingkungan rumah, sekolah, dan masyarakat). Pendidikan mempunyai peran yang amat penting untuk menjamin perkembangan dan kelangsungan kehidupan bangsa. Suatu bangsa yang miskin sumber daya alamnya namun memiliki sumber daya manusia yang berkualitas yang dibentuk melalui pendidikan akan dapat mencapai keunggulan dan mencapai kemakmuran lebih cepat dibandingkan dengan bangsa yang kaya sumber daya alamnya saja tetapi kurang didukung oleh kualitas sumber daya manusianya.

satu Universitas merupakan salah menyelenggarakan pendidikan formal. Universitas memiliki peranan yang sangat penting dalam mewujudkan tujuan pendidikan nasional melalui proses belajar mengajar. Dalam keseluruhan upaya pendidikan, proses belajar merupakan aktivitas yang paling penting, karena melalui proses itulah tujuan pendidikan akan dicapai dalam bentuk perubahan perilaku atau pribadi mahasiswa. Proses belajar pada dasarnya merupakan interaksi dinamis antara mahasiswa dengan dosen dalam mencapai tujuan yang telah ditetapkan. 
Tujuan pembelajaran adalah untuk mengembangkan potensi peserta didik agar menjadi manusia yang beriman dan bertakwa kepada Tuhan Yang Maha Esa, berakhlak mulia, sehat, berilmu, cakap, kreatif, mandiri, dan menjadi warga Negara yang demokratis serta bertanggung jawab ( UU RI No. 20 Tahun 2003 tentang Sistem Pendidikan Nasional Bab II Pasal 3). Tujuan ini dapat digambarkan dengan hasil belajar dalam bentuk nilai akhir yang diperoleh setiap peserta didik. Di Perguruan Tinggi hasil belajar dapat dilihat dari nilai evaluasi di setiap semester maupun dari rekapitulasi nilai Indeks Prestasi Kumulatif (IPK). IPK merupakan evaluasi hasil yang dilakukan melalui kajian terhadap kinerja mahasiswa meliputi hasil kegiatan pembelajaran pada setiap mata kuliah dan pada keseluruhan mata kuliah (Kurikulum UPI, 2014). Hal ini mengindikasikan bahwa mutu pendidikan dapat dilihat dari nilai ratarata pencapaian Indeks Prestasi Kumulatif (IPK).

Berdasarkan sasaran mutu Program Studi Pendidikan Akuntansi Universitas Pendidikan Indonesia Bandung, rata-rata IPK yang dihapkan sekurang-kurangnya 3,13 (pada skala 4). Jadi IPK IPK lebih besar sama dengan dari $3,13 \quad(\geq 3,13)$ ditujukan untuk menghasilkan mahasiswa dengan IPK yang tinggi serta menjadi tenaga ahli dalam bidang Pendidikan Akuntansi yang lebih baik dan kompeten dalam bidang Pendidikan maupun dalam dunia kerja bidang lain nantinya. Hal ini dapat dilihat dari ratarata nilai IPK mahasiswa Prodi Pendidikan Akuntansi UPI Bandung angkatan 2011, 2012 dan 2013:

Tabel 1

Rata-rata Nilai Indeks Prestasi Kumulatif (IPK) Mahasiswa Prodi Pendidikan Akuntansi UPI Bandung Angkatan 2011, 2012 dan 2013

\begin{tabular}{|c|c|c|c|}
\hline Angkatan & $\begin{array}{c}\text { Jumlah } \\
\text { Mahasiswa }\end{array}$ & IPK $\geq 3.13$ & IPK $<3.13$ \\
\hline 2011 & 88 & 75 & 13 \\
\hline 2012 & 74 & 47 & 27 \\
\hline 2013 & 92 & 52 & 40 \\
\hline Jumlah & 254 & 174 & 80 \\
\hline $\begin{array}{c}\text { Prosentase } \\
(\%)\end{array}$ & $100 \%$ & $68,50 \%$ & $31,50 \%$ \\
\hline
\end{tabular}

Sumber: Seksi Akademik dan Kemahasiswaan FPEB UPI, data diolah

Berdasarkan Tabel 1 dapat diketahui bahwa perolehan data yakni rata-rata IPK dari 254 mahasiswa Prodi Pendidikan Akuntansi Angkatan 2011, 2012 dan 2013 menunjukan prosentase keseluruhan yakni $68.50 \%$ diatas dari IPK yang diharapkan sesuai dengan IPK minimal yang ditetapkan oleh Prodi Pendidikan Akuntansi UPI Bandung yaitu sekurang-kurangnya 3.13 (pada skala 4), sedangkan $31.50 \%$ kurang dari IPK yang diharapkan sesuai ketetapan Prodi Pendidikan Akuntansi UPI Bandung.

Prestasi belajar dipengaruhi oleh tiga faktor utama yaitu faktor internal, faktor eksternal dan faktor pendekatan belajar.

Dari ketiga faktor di atas penulis memusatkan penelitian pada salah satu faktor internal mahasiswa yaitu faktor kecerdasan emosional (EQ) dan minat belajar mahasiswa. Menurut pendapat Goleman (2000 : 4) 
kecerdasan intelektual (IQ) hanya menyumbang $20 \%$ bagi kesuksesan, sedangkan $80 \%$ adalah sumbangan dari faktor kekuatan-kekuatan lain, salah satunya yaitu kecerdasan emosional (EQ). Kecerdasan emosional itu sendiri menurut Goleman merupakan kemampuan untuk memantau dan mengendalikan perasaan sendiri dan orang lain, dan menggunakan perasaan-perasaan itu untuk memadu pikiran dan tindakan. Sesuai yang dipaparkan diatas bahwa kecerdasan emosional itu menggunakan perasaan untuk memadu pikiran dan tindakan, sehingga hasil belajar mahasiswa pun dapat dipengaruhi oleh tingkat kecerdasan emosional mahasiswa tersebut, mahasiswa yang pandai mengontrol emosional nya maka mahasiswa tersebut dapat membagi antara emosi dan kewajiban yang harus di jalaninya. Kewajiban yang dimaksud disini adalah kewajiban belajar mahasiswa yang secara tidak langsung dapat mempengaruhi prestasi belajar mahasiswa. Menurut Goleman (2000 : 4) kecerdasan emosional mampu memperkuat seseorang dalam menggerakkan dan meningkatkan kemampuankemampuan intelegensi yang ada dalam diri seseorang dengan tujuan seseorang tersebut dapat meraih prestasi belajar yang maksimal. Dengan mengelola kecerdasan emosional dalam proses belajar mengajar, tidak hanya mahasiswa yang memiliki IQ tinggi yang dapat berhasil dalam belajar namun mahasiswa yang memiliki IQ rendah juga dapat mencapai hasil belajar yang tinggi pula.

Selain kecerdasan emosional, minat belajar mahasiswapun ikut mendukung dalam pencapaian prestasi belajar, karena jika mahasiswa memiliki minat yang tinggi terhadap sesuatu maka mahasiswa tersebut akan berusaha berjuang untuk mendapatkan yang terbaik dari apa apa yang dia lakukan sesuai dengan minat nya tersebut, dan sebaliknya apabila mahasiswa tidak berminat terhadap sesuatu maka mahasiswa itu akan enggan untuk berusaha dan terlihat acuh dalam menjalankan kewajibannya tersebut. Dengan minat yang tinggi tentunya akan menghasilkan prestasi belajar yang tinggi pula.

Slameto (2010 : 180) menyatakan bahwa minat dapat diukur dari memperhatikan dan mengenang apa yang dipelajari, ada rasa suka dan senang, ada rasa keterikatan, lebih menyukai dari pada yang tidak diminati, dan partisipasi pada kegiatan. Bila seseorang tidak memiliki minat dan perhatian yang besar terhadap objek yang dipelajari maka sulit diharapkan seseorang tersebut akan tekun dan memperoleh prestasi yang baik dari belajarnya. Seperti yang diungkapkan oleh

Efendi dan Praja (2004 : 122) belajar dengan minat akan lebih baik daripada belajar tanpa minat. Hal ini diperkuat dengan pendapat Syah (2003 : 136) minat besar sekali pengaruhnya terhadap aktivitas belajar, karena ada daya tarik baginya.

Tujuan dari penelitian ini adalah untuk mengetahui gambaran kecerdasan emosional dan minat belajar mahasiswa Pendidikan Akuntansi UPI Bandung serta mengetahui pengaruh dari kecerdasan emosional dan minat belajar terhadap prestasi belajar mahasiswa Pendidikan Akuntansi UPI Bandung.

\section{Landasan Teori}

Istilah "kecerdasan emosional" pertama kali dilontarkan pada tahun 1990 oleh psikolog Peter Salovey dari 
Harvard University dan John Mayer dari University of New Hampshire untuk menerangkan kualitas-kualitas emosional yang nampaknya penting bagi keberhasilan. Kecerdasan emosional sangat dipengaruhi oleh lingkungan, tidak bersifat menetap, dapat berubah-ubah setiap saat. Untuk itu peran lingkungan terutama orang tua pada masa kanak-kanak sangat mempengaruhi dalam pembentukan kecerdasan emosional. Terdapat lima indikator untuk mengukur kecerdasan emosional seseorang yaitu: mengenali emosi diri, mengelola emosi, memotivasi diri sendiri, mengenali emosi orang lain, dan membina hubungan.

Minat adalah kecenderungan yang mengarahkan manusia terhadap bidang-bidang yang ia sukai dan tekuni tanpa adanya keterpaksaan dari siapapun. Minat pula yang mengarahkan manusia untuk berprestasi dalam berbagai hal atau bidang yang ia sukai dan tekuni. Seseorang yang mempunyai minat terhadap sesuatu hal atau bidang tertentu, maka ia akan mengarahkan dirinya terhadap bidang tersebut dan senang menekuninya dangan sungguh-sungguh tanpa adanya paksaan. Setia (2007) yang mengutip Krapp mengkategorikan minat menjadi 3 yaitu :

1) Minat Personal, yaitu minat yang permanen dan stabil yang mengarah pada minat khusus mata pelajaran tertentu. Suatu bentuk rasa senang ataupun tidak senang, tertarik dan tidak tertarik terhadap mata pelajaran tertentu.

2) Minat Situasional, yaitu minat yang tidak permanen dan relatif berganti-ganti tergantung rangsangan eksternal. Misalnya cara mengajar guru, suasana kelas, dorongan keluarga. Jika berkelanjutan secara jangka panjang, minat situasional akan berubah menjadi minat personal. Minat psikologis siswa, tergantung pada dorongan atau rangsangan yang ada.

3) Minat Psikologikal, minat yang erat kaitannya dengan adanya pengaruh antara minat personal dengan minat situasional yang terus menerus berkesinambungan. Jika siswa memiliki pengetahuan yang cukup tentang suatu mata pelajaran dan dia memiliki peluang untuk mendalaminya dalam aktivitas yang terstruktur dikelas atau pribadi (diluar kelas) serta mempunyai penilaian yang tinggi atas mata pelajaran tersebut maka dapat dinyatakan bahwa siswa memiliki minat psikologikal.

Indikator minat yaitu: Mempunyai kecenderungan yang tetap untuk memperhatikan dan mengenang sesuatu yang dipelajari secara terus menerus.

1) Ada rasa suka dan senang pada sesuatu yang diminati.

2) Memperoleh suatu kebanggaan dan kepuasan pada sesuatu yang diminati. Ada rasa keterikatan pada sesuatu aktivitas-aktivitas yang diminati.

3) Lebih menyukai suatu hal yang menjadi minatnya daripada yang lainnya.

4) Dimanifestasikan melalui partisipasi pada aktivitas dan kegiatan.

Prestasi belajar merupakan hasil yang dicapai seseorang setelah terjadinya proses belajar mengajar. Menurut Sardiman (2004 : 28-29) bahwa "prestasi belajar itu meliputi hal 
ihwal keilmuan dan pengetahuan, konsep atau fakta (kognitif) ; hal inwal personal, kepribadian atau sikap (afektif), serta hal ihwal kelakuan, keterampilan atau penampilan (psikomotorik)". Pendapat lain mengatakan yaitu menurut Ahmadi dan Supriyono (2004 : 138) bahwa "prestasi belajar merupakan hasil interaksi berbagai faktor yang mempengaruhinya baik dari dalam diri (faktor internal) maupun dari luar diri (faktor eksternal) individu". Sedangkan menurut Syah (2008: 216), prestasi belajar ideal meliputi segenap ranah psikologis yang berubah sebagai akibat pengalaman dan proses belajar siswa.

Prestasi belajar di pengaruhi oleh banyak faktor menurut Syah (2011 : 129) ada tiga faktor yang mempengaruhi prestasi belajar, yaitu :

1. Faktor internal (faktor dari dalam siswa), meliputi dua aspek yakni

a. Aspek fisiologis (yang bersifat jasmaniah), seperti kuat lemahnya organ tubuh.

b. Aspek psikologis (yang bersifat rohaniah), meliputi : intelegensi/ atau kecerdasan siswa, sikap siswa, bakat siswa, minat siswa dan motivasi siswa.

2. Faktor eksternal (faktor dari luar siswa), yang meliputi dua aspek juga yakni :

a. Lingkungan sosial, seperti : lingkungan keluarga, guru, staf, masyarakat dan teman.

b. Lingkungan nonsosial : lingkungan rumah, sekolah, peralatan dan alam.

3. Faktor pendekatan belajar (approach to learning), yakni jenis upaya belajar siswa yang meliputi strategi dan metode yang digunakan siswa untuk melakukan kegiatan mempelajari materi-materi pelajaran. Meliputi pendekatan tinggi (speculative dan achieving), pendekatan sedang (analitical dan deep) dan pendekatan rendah (reproductive dan surface).

\section{Metode Penelitian}

Metode yang digunakan dalam penelitian ini adalah metode penelitian deskriptif verifikatif. Menurut Sugiyono (2010 : 11) "metode penelitian deskriptif adalah metode penelitian yang dilakukan untuk mengetahui variabel, baik satu variabel atau lebih tanpa membuat perbandingan atau menghubungkan antara variabel satu dengan yang lainnya". Melalui penelitian survei verifikatif ini, maka diperoleh gambaran mengenai "Pengaruh kecerdasan emosional dan minat belajar terhadap prestasi belajar mahasiswa Pendidikan Akuntansi UPI Bandung".

Populasi dalam penelitian ini Akuntansi UPI Bandung Angkatan 2011, 2012 dan 2013 yang berjumlah 254 mahasiswa. Dan akan di ambil sampel dengan menggunakan rumus $n_{i}=\frac{N_{i}}{N} \times n$

Keterangan :

$\mathrm{N}=$ Ukuran populasi

$N_{i}=$ Ukuran populasi stratum ke 1

$\mathrm{n}=$ Ukuran sampel keseluruhan

$n_{i}=$ Ukuran sampel

Berikut adalah tabel sampel mahasiswa Pendidikan Akuntansi Angkatan 2011, 2012 dan 2013 UPI Bandung. 
Tabel 2

Data Jumlah Mahasiswa Pendidikan Akuntansi Angkatan 2011, 2012 dan 2013 UPI Bandung

\begin{tabular}{|c|c|c|}
\hline Angkatan & Populasi & Sampel \\
\hline 2011 & 88 & 54 \\
\hline 2012 & 74 & 45 \\
\hline 2013 & 92 & 56 \\
\hline Jumlah & 254 & 155 \\
\hline \multicolumn{2}{|c|}{ Sumber: Data penelitian , diolah kembali }
\end{tabular}

Penelitian ini akan menggunakan teknik Simple Random Sampling yaitu teknik sampling yang dapat memilih sampel nya secara acak berdasarkan Nomor Induk Mahasiswa setiap angkatannya, dengan cara mengkocok nomor induk mahasiswa Pendidikan Akuntansi setiap angkatannya, maka yang keluar dari kocokan berhak untuk mengisi angket penelitian ini. Semua mahasiswa yang menjadi populasi disini memiliki kesempatan yang sama untuk menjadi sampel. Teknik pengolahan data dilakukan dengan cara pembagian angket.

Analisis yang digunakan dalam penelitian ini adalah analisis regresi linier multipel. Sebelum analisis data terlebih dahulu dilakukan uji normalitas. Uji normalitas dilakukan dengan tujuan untuk mengetahui apakah data berdistribusi normal atau tidak, sehingga dapat menetukan jenis statistika yang akan digunakan. Data dikatakan berdistribusi normal jika nilai signifikansinya lebih besar dari 0,05. Berdasarkan perhitungan dengan menggunakan metode Kolmogorov Smirnov, nilai signifikansi (Asymp. Sig 2-tailed) untuk variabel kecerdasan emosional sebesar 0,277 lebih dari 0,05 , maka variabel kecerdasan emosional berdistribusi normal. Nilai signifikansi (Asymp. Sig 2-tailed) untuk variabel minat belajar sebesar 0,097 lebih besar dari 0,05, maka variabel minat belajar berdistribusi normal. Nilai signifikansi (Asymp. Sig 2-tailed) untuk variabel prestasi belajar yang digambarkan dengan IPK sebesar 0,620 lebih dari 0,05 , maka variabel prestasi belajar yang digambarkan dengan IPK berdistribusi normal.

Selanjutnya menetapkan hipotesis sebagai berikut:
1. Kecerdasan emosional berpengaruh terhadap prestasi belajar.

2. Minat be;ajar berpengaruh terhadap prestasi belajar.

\section{Hasil dan Pembahasan}

Variabel kecerdasan emosional dalam penelitian ini di ukur melalui lima indikator, yaitu mengenali emosi diri, mengelola emosi, memotivasi diri sendiri, mengenali emosi orang lain, dan membina hubungan. Dari lima indikator tersebut akan diuraikan menjadi 30 pernyataan dengan 5 alternatif jawaban yang dijadikan ukuran tentang variabel kecerdasan emosional. Kategori jawaban responden terbagi menjadi tiga yaitu rendah, sedang dan tinggi. 
Berdasarkan kriteria tersebut dapat tergambar kecerdasan emosional mahasiswa Pendidikan Akuntansi UPI bandung seperti dalam tabel di bawah ini:

Tabel 3

Kecerdasan Emosional Mahasiswa Pendidikan Akuntansi Angkatan 2011, 2012 dan 2013 UPI Bandung

\begin{tabular}{|c|c|c|c|}
\hline Kriteria Penilaian & Interval & Frek & $\%$ \\
\hline Rendah & $55-81$ & 23 & $14,84 \%$ \\
\hline Sedang & $82-108$ & 58 & $37,42 \%$ \\
\hline Tinggi & $109-138$ & 74 & $47,74 \%$ \\
\hline \multicolumn{2}{|l|}{ Jumlah } & 155 & $100 \%$ \\
\hline
\end{tabular}

Sumber: skor jawaban responden

Dari tabel di atas diketahui secara umum kecerdasan emosional mahasiswa Pendidikan Akuntansi UPI angkatan 2011, 2012 dan 2013 UPI Bandung, sebagian kecil mahasiswa berada dalam kategori rendah yang artinya mahasiswa tidak mengenali emosi dirinya, tidak dapat mengelola emosinya, tidak dapat memotivasi dirinya sendiri, tidak dapat mengenali emosi orang lain, dan tidak dapat membina hubungan dengan baik. Sebagian kecil mahasiswa berada pada pada kategori sedang yang artinya mahasiswa cukup mengenali emosi dirinya, cukup dapat mengelola emosinya, cukup dapat memotivasi dirinya sendiri, cukup dapat mengenali emosi orang lain, dapat membina hubungan dengan cukup baik. Akan tetapi hampir setengahnya dari sampel mahasiswa berada pada kategori tinggi yang artinya hampir setengahnya dari sampel mahasiswa sangat mengenali emosi dirinya, sangat dapat mengelola emosinya, dapat memotivasi dirinya sendiri dengan sangat baik, sangat dapat mengenali emosi orang lain, dapat membina hubungan dengan sangat baik.

Terdapat 18 pernyataan dengan 5 alternatif jawaban yang dijadikan ukuran tentang variabel minat belajar dalam penelitian ini, dengan tiga kriteria penilaian yaitu rendah, sedang dan tinggi. Berdasarkan kriteria tersebut dapat tergambar minat belajar mahasiswa Pendidikan Akuntansi UPI Bandung seperti dalam tabel di bawah ini :

Tabel 4

Minat Belajar Mahasiswa Pendidikan Akuntansi Angkatan 2011, 2012 dan 2013 UPI Bandung

\begin{tabular}{|l|c|c|c|}
\hline Kriteria Penilaian & $\begin{array}{c}\text { Kelas } \\
\text { Interval }\end{array}$ & Frekuensi & $\%$ \\
\hline Rendah & $24-43$ & 18 & $11,61 \%$ \\
\hline Sedang & $44-63$ & 73 & $47,10 \%$ \\
\hline Tinggi & $64-83$ & 64 & $41,29 \%$ \\
\hline Jumlah & 155 & $100 \%$ \\
\hline
\end{tabular}

Sumber: skor jawaban responden 


\begin{abstract}
Dari tabel di atas diketahui secara umum minat belajar mahasiswa Pendidikan Akuntansi UPI angkatan 2011, 2012 dan 2013 UPI Bandung, sebagian kecil mahasiswa berada di kategori rendah yang artinya sebagian kecl mahasiswa tidak mempunyai kecenderungan untuk tetap memperhatikan dan mengenang pembelajaran, hampir setengah dari sampel mahasiswa berada di kategori tinggi yang artinya hampir setengah dari sampel mahasiswa mempunyai kecenderungan untuk tetap memperhatikan dan mengenang pembelajaran dengan sangat baik, dan setengah dari sampel mahasiswa berada di kategori sedang yang artinya setengah dari sampel mahasiswa kecenderungan untuk tetap memperhatikan dan mengenang pembelajaran dengan cukup baik.
\end{abstract}

Berdasarkan analisis data dan pengujian hipotesis yang telah dilakukan, maka dapat dijelaskan bahwa terdapat pengaruh antara kecerdasan emosional dan prestasi belajar dengan indikator IPK pada mahasiswa Pendidikan Akuntansi UPI Bandung. Hal ini diketahui dari hasil perhitungan SPSS, Nilai Regresi Linier Multipel $\hat{Y}=1,429+0,005 X_{1}+$ $0,021 X_{2}$ yang artinya jika tidak ada perubahan nilai variabel kecerdasan emosional (X1) dan minat belajar (X2) maka nilai variabel indeks prestasi kumulatif (Y) sebesar 1,426. Untuk nilai koefisien regresi kecerdasan emosional (X1) adalah bernilai positif. Artinya berpengaruh positif/searah, yaitu apabila kecerdasan emosional naik (dengan asumsi variabel lainnya konstan), maka indeks prestasi kumulatif mahasiswa ikut naik.
Untuk melihat keberartian regresi maka digunakan Uji F dengan bantuan SPSS dengan membandingkan $F_{\text {hitung }}$ dengan $F_{\text {tabel }}$. Nilai $F_{\text {tabel }}$ diperoleh dari tingkat signifikansi 0,05 dengan derajat kebebasan df $1-$ $\mathrm{k}$ atau jumlah variabel bebas $=2$, dan derajat kebebasan df $2=(n-k-1)=$ $155-2-1=152$, dimana $n$ adalah jumlah data, maka diperoleh $F_{\text {tabel }}=$ 3,06 .

Dengan kriteria sebagai berikut :

- Jika nilai $F_{\text {hitung }}>$ nilai $F_{\text {tabel }}$, maka $H_{0}$ ditolak dan $H_{1}$ diterima.

- Jika nilai $F_{\text {hitung }} \leq$ nilai $F_{\text {tabel }}$, maka $H_{0}$ diterima dan $H_{1}$ diterima.

Karena $F_{\text {hitung }}>$ nilai $F_{\text {tabel }}$ yaitu 494,062 > 3,06 maka $H_{0}$ ditolak dan $H_{1}$ diterima, artinya bahwa regresi berarti, dengan demikian regresi dapat digunakan untuk mengambil kesimpulan. Berdasarkan uji signifikansi menggunakan uji $t$ diperoleh nilai thitung sebesar 5,675 sedangkan nilai tabel dengan derajat kebebasan $\mathrm{df}=\mathrm{n}-\mathrm{k}-1(\mathrm{df}=155-2-1=152)$, dengan taraf kepercayaan $95 \%$ atau $\alpha$ $=0,05$ didapatkan $t_{\text {tabel }} 0,67611$. Hal ini menunjukkan bahwa thitung $>t_{\text {tabel }}$ $(5,675>0,67611)$. Oleh karena itu, maka dapat disimpulkan bahwa hipotesis yang diajukan yaitu "Kecerdasan Emosional berpengaruh terhadap Prestasi Belajar Mahasiswa Pendidikan Akuntansi UPI Bandung"

Berdasarkan analisis data dan pengujian hipotesis yang telah dilakukan, maka dapat dijelaskan bahwa terdapat pengaruh antara minat belajar dan prestasi belajar dengan indikator IPK pada mahasiswa Pendidikan Akuntansi UPI Bandung. Hal ini diketahui dari hasil perhitungan SPSS, Nilai Regresi Linier Multipel IPK $=1,429+0,005 X_{1}+0,021 X_{2}$ yang artinya jika tidak ada perubahan nilai 
variabel kecerdasan emosional (X1) dan minat belajar (X2) maka nilai variabel indeks prestasi kumulatif $(\mathrm{Y})$ sebesar 1,426. Untuk nilai koefisien regresi minat belajar (X2) adalah bernilai positif. Artinya berpengaruh positif/searah, yaitu apabila minat belajar naik (dengan asumsi variabel lainnya konstan), maka indeks prestasi kumulatif mahasiswa ikut naik.

Berdasarkan uji signifikansi menggunakan uji t diperoleh nilai $t_{\text {hitung }}$ sebesar 26,112 sedangkan nilai $t_{\text {tabel }}$ dengan derajat kebebasan $\mathrm{df}=\mathrm{n}-\mathrm{k}$ $1(\mathrm{df}=155-2-1=152)$, dengan taraf kepercayaan $95 \%$ atau $\alpha=0,05$ didapatkan tabel 0,67611 . Hal ini menunjukkan bahwa thitung $>t_{\text {tabel }}$ $(26,112>0,67611)$. Oleh karena itu, maka dapat disimpulkan bahwa hipotesis yang diajukan yaitu "Minat Belajar berpengaruh terhadap Prestasi Belajar Mahasiswa Pendidikan Akuntansi UPI Bandung" diterima pada taraf kepercayaan $95 \%$.

\section{Simpulan}

Berdasarkan analisis data, pengujian hipotesis serta pembahasan hasil penelitian, maka dapat ditarik kesimpulan sebagai berikut :

1. Hasil penelitian menunjukan bahwa kecerdasan emosional mahasiswa Pendidikan Akuntansi Universitas Pendidikan Indonesia berada pada kategori tinggi. Hal ini menunjukan bahwa sebagian besar mahasiswa Pendidikan Akuntansi UPI Bandung sudah dapat mengenali emosi diri dengan baik, sudah dapat mengelola emosi diri dengan baik, sudah dapat memotivasi diri sendiri dengan baik, dapat mengenali emosi orang lain (empati) dan memiliki kemampuan untuk membina hubungan kerjasama (keterampilan sosial) dengan orang lain dengan sangat baik.
2. Hasil penelitian menunjukan bahwa minat belajar mahasiswa Pendidikan Akuntansi Universitas Pendidikan Indonesia berada pada kategori sedang. Hal ini menunjukan bahwa sebagian besar mahasiswa Pendidikan Akuntansi UPI Bandung cukup mempunyai kecenderungan untuk tetap memperhatikan pembelajaran Akuntansi, cukup menyukai pembelajaran Akuntansi, cukup bangga, cukup puas, dan cukup merasa terikat dengan pembelajaran Akuntansi, cukup menyukai pembelajaran Akuntansi, dan cukup berperan aktif dalam pembelajaran Akuntansi.

3. Prestasi belajar mahasiswa yang dapat dilihat dari nilai indeks prestasi kumulatif mahasiswa Pendidikan Akuntansi UPI Bandung berada pada kategori tinggi yang artinya hampir seluruh mahasiswa Pendidikan Akuntansi telah mendapatkan prestasi belajar yang tinggi bila dilihat dari nilai IPK diatas nilai minimal sebesar 3,13 .

\section{Daftar Pustaka}

Ahmadi, A. dan Supriyono, W (2004) Psikologi Belajar Edisi Revisi. Jakarta: PT Rineka Cipta

Efendi,E,S dan Praja,J,S (2004). Pengantar Psikologi. Bandung: Angkasa.

Goleman, D (2000), Working With Emotional Intelegence. Jakarta: Gramedia Pustaka Utama

Sardiman (2004), Interaksi dan Motivasi Belajar Mengajar. Jakarta: PT Raja Grafindo Persada

Seksi Akademik dan Kemahasiswaan FPEB (2014), Sasaran Mutu Program Studi Pendidikan Akuntansi tahun 2014 


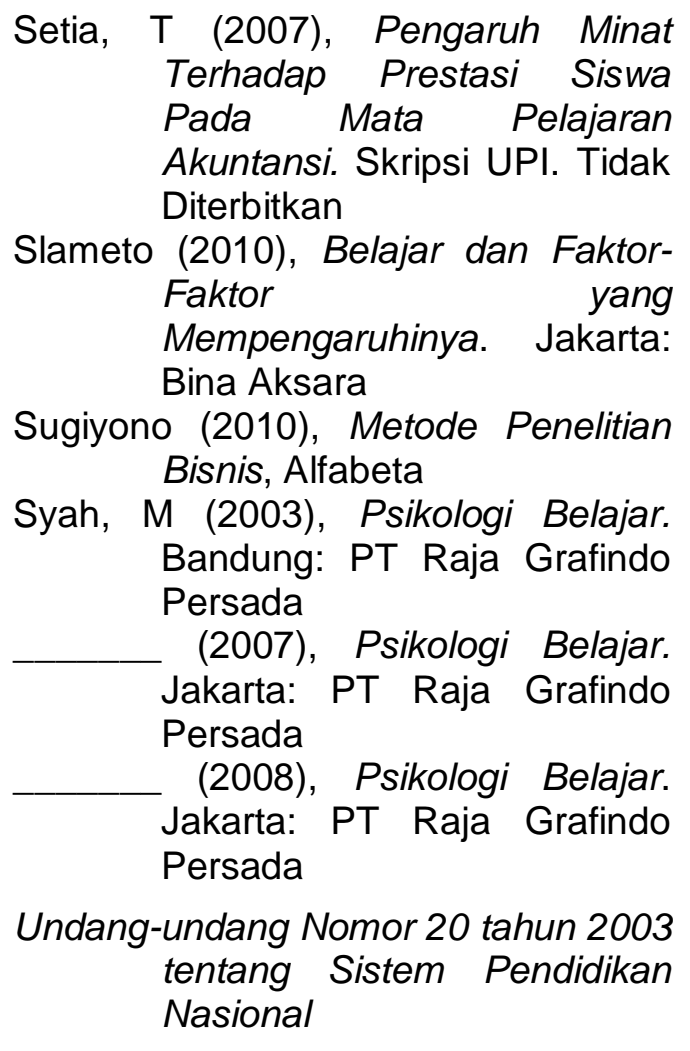

